\title{
TO THE QUESTION OF THE LEGAL APPROXIMATION BETWEEN THE EUROPEAN UNION AND THE RUSSIAN FEDERATION
}

\author{
Dmitriy V. Galushko*
}

\begin{abstract}
The paper gives description of the process of convergence of norms of legal systems of the European Union and the Russian Federation - their approximation. The regulatory framework for this process is considered, and its development trends are also characterized. The author analyzes the essential elements of the approximation process, notes his unilateral nature in relation to the legal system of the Russian Federation, indicating that Russia has no opportunity to influence the EU rulemaking. The reasons that reduce effectiveness of the process of legal approximation of Russian law with law of the European Union are distinguished.
\end{abstract}

KEYWORDS: approximation, convergence, the European Union, the Russian Federation, the Partnership and Cooperation Agreement of 1994, a pragmatic approach.

\section{INTRODUCTION**}

The modern world exists in conditions of ever growing mutual influence and interdependence in the field of politics, law, economy, science and culture. Such interaction expands with the deepening of contacts between countries, peoples, organizations, enterprises, public associations. This process is also affected by legal systems of various states and international entities.

\footnotetext{
* Associate Professor of the Department for Theory of State and Law, International Law and Comparative Law, Voronezh State University; galushkodv@gmail.com.

** The paper was developed as a part of the Jean Monnet Module «EU-Russia Law Approximation» PROJECT NUMBER-564684-EPP-1-2015-1-RU-EPPJMOMODULE.
} 
The most important direction of cooperation between states in the field of legal policy is creation of unified or uniform legal prescriptions intended for regulation of certain social relations. This legal phenomenon has been called approximation. Interstate interaction on approximation of national legal systems has a long history and covers a wide range of areas of legal regulation. Beginning with shy attempts to create uniform legal regulation, work on convergence of laws has now acquired such large scale that approximation is viewed as a global phenomenon and a comprehensive one, the intensity of which will constantly increase.

The process of legal approximation can be also seen on an example of the European Union and the Russian Federation interaction. The European Union inevitably influences Russian legal and economic orders as parts of globalized world economy as the both sides possess different strong bilateral interests.

\section{LEGAL FRAMEWORK FOR THE APPROXIMATION PROCESS}

The basis for the relationship between Russia and the European Union is the Agreement on partnership and cooperation establishing a partnership between the European Communities and their Member States, of one part, and the Russian Federation, of the other part, 1994 (hereinafter — the 1994 Agreement) ${ }^{1}$. Since its entry into force, according to Article 112 of the Agreement, this document replaces the Agreement between the European Economic Community and the European Atomic Energy Community and the Union of Soviet Socialist Republics on trade and commercial and economic cooperation, signed in Brussels on December 18, $1989^{2}$.

Article 1 of the Agreement provides, that a Partnership is hereby established between the Community and its Member States, of the one part, and Russia, of the other part. The objectives of this Partnership are:

- to provide an appropriate framework for the political dialogue between the Parties allowing the development of close relations between them in this field,

\footnotetext{
1 Agreement on partnership and cooperation establishing a partnership between the European Communities and their Member States, of one part, and the Russian Federation, of the other part, 1994. URL: http://ec.europa.eu/world/agreements/prepareCreateTreatiesWorkspace/treatiesGeneralData.do?step=0\&redirect=true \& treatyId=201 (1.12.2017)

2 Agreement between the European Economic Community and the European Atomic Energy Community and the Union of Soviet Socialist Republics on trade and commercial and economic cooperation, 1989. URL: http://ec.europa.eu/world/agreements/prepareCreateTreatiesWorkspace/treatiesGeneralData.do?step=0\&redirect=true\&treatyId=5981 (1.12.2017)
} 
- to promote trade and investment and harmonious economic relations between the Parties based on the principles of market economy and so to foster sustainable development in the Parties,

- to strengthen political and economic freedoms,

- to support Russian efforts to consolidate its democracy and to develop its economy and to complete the transition into a market economy,

- to provide a basis for economic, social, financial and cultural cooperation founded on the principles of mutual advantage, mutual responsibility and mutual support,

- to promote activities of joint interest,

- to provide an appropriate framework for the gradual integration between Russia and a wider area of cooperation in Europe,

- to create the necessary conditions for the future establishment of a free trade area between the Community and Russia covering substantially all trade in goods between them, as well as conditions for bringing about freedom of establishment of companies, of cross-border trade in services and of capital movements.

The Russian Federation ratified this Agreement by Federal Law of November 25, 1996 ${ }^{3}$. The Agreement came into force on December 1, 1997 after being ratified by the European Parliament and all national parliaments of the EU member states.

The 1994 Agreement contains general provisions on cooperation between the European Union and Russia, since many of its provisions need further development and specification within the framework of special bilateral agreements on certain issues. Some articles of the Agreement do not justify the possibility, but even the necessity of concluding such agreements (for example, articles 21-22) . $^{4}$

Article 55 enshrined provisions for cooperation in the field of legislation, recognizing that an important condition for strengthening economic ties between Russia and the Community is approximation of legislation. Russia seeks to gradually achieve the compatibility of its legislation with the legislation of

\footnotetext{
3 Federal'nyj zakon ot 25.11.1996 g. № 135-FZ O ratifikacii Soglashenija o partnerstve i sotrudnichestve, uchrezhdajushhego partnerstvo mezhdu Rossijskoj Federaciej, s odnoj storony, i Evropejskimi soobshhestvami i ih gosudarstvami-chlenami, s drugoj storony. URL: http://www.kremlin.ru/acts/bank/10283 (1.12.2017)

4 Kashkin S. Ju. Strategija i mehanizmy garmonizacii zakonodatel'stva Rossii i Evropejskogo Sojuza kak kljuchevye komponenty ih jeffektivnogo vzaimorazvitija v XXI v. // Tendencii rossijsko-evropejskih otnoshenij. 2005. № 6. S. 41-76.
} 
the Community. Part 2 of this article indicates that it covers, in particular, the following branches of law: company law, banking law, company accounts and taxes, protection of workers at the workplace, financial services, rules on competition, public procurement, protection of health and life of humans, animals and plants, the environment, consumer protection, indirect taxation, customs law, technical rules and standards, nuclear laws and regulations, transport.

The provisions of the Agreement on legal approximation between the Contracting Parties were of a framework nature, and their implementation required adoption of appropriate legal acts, development of necessary institutional mechanisms and implementation of relevant actions both internationally within the relations between the Parties and within the legal order of the Russian Federation.

\section{NATURE OF EU-RUSSIA LAW APPROXIMATION}

The complexity of analysis of features of legal approximation of law is due to the fact, that it is a long and dynamic process, a certain sequence of interrelated actions to change the existing legal order, each link of which is logically connected with other elements, together forming a program for development of the legal system. Accordingly, when solving problems on approximation of legislation, a state actually determines its own development path.

The approximation process is a manifestation of the dynamic, evolutionary dimension of law, a way of realizing of its modernization function, which has been actualized with a new force on a new round of social progress. Approximation characterizes the process of bringing legislation into line with EU law, but it occurs outside the European Union and concerns third countries (in this particular case - the Russian Federation) in connection with implementation of their foreign policy course for cooperation with the European Union. The main goal of approximation is to create the same legal conditions for subjects of cooperation between Russia and the European Union.

Approximation envisages a process of general, coordinated development of national legislation, elimination of existing contradictions and formation of minimum legal standards through approval of general legal principles or adoption of separate legal solutions with a view to convergence of legal systems. Such convergence through a number of objective factors (for example, political and legal uniqueness of a state) does not reach the degree of absolute identity of laws of relevant countries and EU law.

As professor Yu. Tikhomirov argues, in general, the process of convergence of national legal systems provides: 
- development of a common policy of state legal development;

- implementation of measures to overcome legal differences;

- taking measures to develop joint legal rules ${ }^{5}$.

It can be argued that the goal of legal approximation will be achievable to the extent that its mechanism in the relevant state turns out to be effective, including its institutional and normative parts. With its help the state of progress, with which changes in legislation are linked, acquires features of a balanced and realistic program. Nevertheless, in the Russian Federation, at the legislative level, the problem of determining the order of approximation of the legal systems of the Russian Federation and the European Union, its essential elements and the degree of convergence of the Russian legislation with the norms of EU law as a result of the approximation process, remains finally unresolved.

Unlike the extent of legal harmonization of member states within the European Union, the scope of the third countries' legislation, which is subject to approximation, is being defined very differently. It depends on areas of cooperation, agreed upon by mutual agreement, on the level of cooperation between the parties and on the specifics of the legal status of the third country (partner-country, neighbor country, applicant country, candidate country) on the basis of relevant international agreements, in the case of the Russian Federation - the 1994 Agreement.

As a rule, the provisions of agreements, relating to approximation of national legislation of third countries with EU law, depend on the areas in which convergence takes place. However, in the process of determining these areas, the special character of relations of the European Union with this particular country has been always taken into account. The spheres have been determined directly during negotiations on conclusion of such agreements. At the same time, third countries, given the principled nature of some of their national interests, can express certain protective reservations on impossibility of perceiving some of the provisions of the EU legal order. That is, the specific content of the acquis communautaire may differ depending on the parties' approaches to determining the level and purposes of their cooperation ${ }^{6}$.

During implementation of the approximation process, third countries deal with the same EU acts. However, in practice, there is a selective approach, when, for particular countries, depending on objectives and areas of cooperation agreed upon by an agreement with the European Union, from the whole acquis com-

Tihomirov Yu.A. Kurs sravnitel'nogo pravovedenija. - M.: NORMA, 1996. - S. 74.

6 Ghazaryan N. The European Neighbourhood Policy and the Democratic Values of the EU: A Legal Analysis. - Oxford: Hart Publishing, 2014. P. 68-72. 
munautaire specifically are select those acts, which implementation must ensure that the parties fulfill their obligations. In relation to the Russian Federation, these areas were defined in Part 2 of Article 55 of the 1994 Agreement.

Since the 1994 Agreement is of a general nature, the Parties have adopted Road maps on EU-Russia four common spaces to specify its provisions and develop mechanisms for implementation of cooperation ${ }^{7}$. These common spaces cover economic issues and the environment; issues of freedom, security and justice; external security, including crisis management and non-proliferation; and research and education, including cultural aspects. The documents include, inter alia, a set of interrelated tasks on the process of adaptation of Russian legislation to law of the European Union aimed at implementing state policy and priority directions for the development of the legal system of the Russian Federation by improving the standard-setting activities of public authorities and work on legal convergence in relevant areas. Determination of these norms, in our opinion, is due to the fact that in a rule-of-law state there cannot be other means of implementation of public priorities, except legal ones. Nevertheless, a national legal act, which could fully determine the procedure for fulfilling Russia's obligations on EU-Russia law approximation, form the normative and institutional basis for the process, was not accepted.

During the process of approximation, Russia should take into account that this process is unilateral, since it does not mean mutual steps of both sides on harmonization of their legal norms, but only changes in Russian legislation with a view to their convergence with the norms of European Union law ${ }^{8}$.

The Russian Federation cannot influence law-making processes in the European Union system, it is not capable of changing the norms of EU law and of its own will to create with EU member states the Union's joint legal space. Thus it's happen only involvement of a third country to the already existing rules of law of the European Union. Such a «one-sided approach», in our view, is largely characteristic of the provisions of the 1994 Agreement and one of the most problematic aspects of the relationships between the two Parties.

Based on the content of the 1994 Agreement, it can be noted, that it deals with relatively broad areas of legal regulation. Its scope deeply penetrates into the domestic policy and legislation of the Russian Federation, requires the govern-

\footnotetext{
EU-Russia: Road Map for the Common Spaces. URL: http://library.euneighbours.eu/content/eu-russia-road-map-common-spaces (1.12.2017)

8 Galushko D. V. K voprosu o vlijanii prava Evropejskogo Sojuza na pravoporjadki tret'ihstran // Pravovoe regulirovanie: problemy jeffektivnosti, legitimnosti, spravedlivosti: Sbornik trudov mezhdunarodnoj nauchnoj konferencii (Voronezh, 02-04 ijunja 2016 g.). Voronezh: NAUKA-JuNIPRESS, 2016. S. 400.
} 
ment to implement far-reaching efforts to adapt domestic legislation in various directions. At the same time, if Russia does not properly approximate its legislation with EU law, this circumstance may create obstacles to the further process of its cooperation with the EU, however, it does not entail the imposition of any legal sanctions?.

Approximation of systems of national Russian law and EU law cannot be conducted mechanically. First, the principle of state sovereignty continues to operate. Secondly, there are still no universal organizational mechanisms for approximation of relevant legal systems. Thirdly, there are significant problems of a political nature in the relations between the Parties at the present. All this hinders practical implementation of the relevant provisions regulating cooperation between the Russian Federation and the European Union.

Nevertheless, the approximation process continues and gradually develops pragmatically, despite numerous problematic factors, primarily of political nature in the relations between Russia and the EU ${ }^{10}$. Special successes on EU-Russia law approximation can be highlighted in spheres of higher education, transport, technical regulation, corporate law. The will of relevant competent public authorities of the Russian Federation is due to absolutely justified and pragmatic reasons: the EU is Russia's largest trading partner with $44 \%$ of the total trade turnover. In turn, for the European Union, Russia is the third largest trading partner after the United States and China ${ }^{11}$.

In addition, a result of approximation is that in national law there appears a system of not only general, but also specific principles of law, a single mechanism for legal regulation of social relations. This is particularly relevant in the context of establishing partnership relations not only with the European Union, but also within the framework of the Eurasian Economic Union, the Commonwealth of Independent States, the World Trade Organization, requiring the coordination of legal policies within these international associations ${ }^{12}$. In particular, no one denies the importance of European Union's experience in Eurasian integration building, but, on the contrary, it has been underlined

9 See: Kalinichenko P.A. Rossija i Evropejskij Sojuz: dvustoronnjaja normativnaja baza vzaimootnoshenij: monografija / P.A. Kalinichenko. - M.: OOO «Izd-vo "Jelit"», 2011.

10 See: Jentin M.L., Jentina E.G. V poiskah partnjorskih otnoshenij VI: Rossija i Evropejskij Sojuz v 2015-2016 godah: Nauchnaja monografija. M., 2017.

11 Permanent Mission of the Russian Federation to the European Union: Brief overview of relations. URL: https://russiaeu.ru/en/brief-overview-relations (1.12.2017)

12 Mishal'chenko Ju.V., Toropygin A.V., Belousov S.N. O sotrudnichestve gosudarstv-chlenov Tamozhennogo sojuza i Edinogo jekonomicheskogo prostranstva s Evropejskim sojuzom // Upravlencheskoe konsul'tirovanie. 2013. №5 (53) S. 84-88. 
in every possible way, including Russian President Vladimir Putin in his programmatic article on the future of the Eurasian Union ${ }^{13}$.

\section{CONCLUSION}

As international experience shows, the mechanism of legal approximation depends on the features of a legal, political, economic system of each of the countries. For the Russian Federation, approximation of national legislation with the law of the European Union is of particular importance and topicality, since this process involves not only the creation of a legal framework for relations with the EU, but also the achievement of other important goals for Russia, namely, creation of mechanisms for implementation of economic reforms, improving competitiveness of Russian economy, facilitating attraction of foreign investments into Russian economy, development of foreign trade between the Russian Federation and the European Union and the entire range of mutual trade and economic relations, further democratization of social processes, development of basic principles on functioning of civil society in accordance with European standards, development of higher education.

\section{LITERATURE:}

1. Agreement on partnership and cooperation establishing a partnership between the European Communities and their Member States, of one part, and the Russian Federation, of the other part, 1994. URL: http://ec.europa.eu/world/agreements/prepareCreateTreatiesWorkspace/treatiesGeneralData.do?step=0\&redirect=true \& treatyId=201 (1.12.2017)

2. Agreement between the European Economic Community and the European Atomic Energy Community and the Union of Soviet Socialist Republics on trade and commercial and economic cooperation, 1989. URL: http://ec.europa. eu/world/agreements/prepareCreateTreatiesWorkspace/treatiesGeneralData.do?step $=0 \&$ redirect $=$ true \& treatyId $=5981(1.12 .2017)$

3. Federal'nyj zakon ot 25.11.1996 g. № 135-FZ O ratifikacii Soglashenija o partnerstve i sotrudnichestve, uchrezhdajushhego partnerstvo mezhdu Rossijskoj Federaciej, s odnoj storony, i Evropejskimi soobshhestvami i ih gosudarstvami-chlenami, s drugoj storony. URL: http://www.kremlin.ru/acts/bank/10283 $(1.12 .2017)$

13 Putin V. A new integration project for Eurasia: The future in the making ("Izvestia", 3 October 2011). URL: https://russiaeu.ru/en/news/article-prime-minister-vladimir-putin-new-integration-project-eurasia-future-making-izvestia-3- (1.12.2017) 
4. Kashkin S. Ju. Strategija i mehanizmy garmonizacii zakonodatel'stva Rossii i Evropejskogo Sojuza kak kljuchevye komponenty ih jeffektivnogo vzaimorazvitija v XXI v. // Tendencii rossijsko-evropejskih otnoshenij. 2005. № 6. S. 41-76.

5. Agreement on partnership and cooperation establishing a partnership between the European Communities and their Member States, of one part, and the Russian Federation, of the other part // Official Journal L 327, 28/11/1997. P. 0003 - 0069.

6. Tihomirov Yu.A. Kurs sravnitel'nogo pravovedenija. - M.: NORMA, 1996.

7. Ghazaryan N. The European Neighbourhood Policy and the Democratic Values of the EU: A Legal Analysis. - Oxford: Hart Publishing, 2014. P. 68-72.

8. EU-Russia: Road Map for the Common Spaces. URL: http://library.euneighbours.eu/content/eu-russia-road-map-common-spaces (1.12.2017)

9. Galushko D. V. K voprosu o vlijanii prava Evropejskogo Sojuza na pravoporjadki tret'ih-stran // Pravovoe regulirovanie: problemy jeffektivnosti, legitimnosti, spravedlivosti: Sbornik trudov mezhdunarodnoj nauchnoj konferencii (Voronezh, 02-04 ijunja 2016 g.). Voronezh: NAUKA-JuNIPRESS, 2016.

10. Kalinichenko P.A. Rossija i Evropejskij Sojuz: dvustoronnjaja normativnaja baza vzaimootnoshenij: monografija / P.A. Kalinichenko. - M.: OOO «Izd-vo "Jelit”», 2011.

11. Jentin M.L., Jentina E.G. V poiskah partnjorskih otnoshenij VI: Rossija i Evropejskij Sojuz v 2015-2016 godah: Nauchnaja monografija. M., 2017.

12. Mishal'chenko Ju.V., Toropygin A.V., Belousov S.N. O sotrudnichestve gosudarstv-chlenov Tamozhennogo sojuza i Edinogo jekonomicheskogo prostranstva s Evropejskim sojuzom // Upravlencheskoe konsul'tirovanie. 2013. №5 (53) S. 84-88.

13. Putin V. A new integration project for Eurasia: The future in the making ("Izvestia", 3 October 2011). URL: https://russiaeu.ru/en/news/article-prime-minister-vladimir-putin-new-integration-project-eurasia-future-making-izvestia-3$(1.12 .2017)$ 
